\title{
Pathobiology of Helicobacter pylori infection in children
}

\author{
Robert H Riddell MD FRCPath FRCPC
}

RH Riddell. Pathobiology of Helicobacter pylori infection in children. Can J Gastroenterol 1999;13(7):599-603. In the pediatric population, the associations of Helicobacter pylori with gastritis, gastric ulcer, duodenitis and duodenal ulcer, and with duodenal gastric surface metaplasia and disorders of the D cell$G$ cell axis resulting in hypergastrinemia, are well established and in many ways resemble their counterparts in adults. Eradication of $H$ pylori invariably results in the reversal of these diseases with time. There are also suggestions that gastric surface metaplasia is more extensive in children with $H$ pylori, and may be the site of duodenal $\mathrm{H}$ pylori infection and associated duodenal erosions or ulcers. There is no consensus as to whether $H$ pylori in children is more or less severe than in adults. In one pediatric cohort, $\mathrm{H}$ pylori was associated with increased intensity of inflammation, while other studies suggest that acute inflammation may be less intense in children overall but that chronic inflammation may be increased in intensity, including lymphoid hyperplasia, which in turn may correlate with endoscopic nodularity. Lymphoid hyperplasia and nodular gastritis appear to be more frequent in children than in adults and usually regress following $H$ pylori eradication. However, in children, other diseases or morphological abnormalities, including some loss of glands (atrophy), occasionally intestinal metaplasia, lymphoproliferative diseases including low grade mucosal-associated lymphoid tissue lymphoma, lymphocytic gastritis and hypertrophic gastritis/Menetrier's disease, are much less frequently associated with $H$ pylori than in adults. Other associations are rarely seen in children, primarily because the time required for these to develop takes the individual to adulthood; for example, while intestinal metaplasia occurs in the pediatric population, the complications of adenoma/dysplasia and carcinoma are rare. In adults, inflammatory and hyperplastic polyps, atrophic gastritis and pernicious anemia, and in some patients granulomas (granulomatous gastritis), may also be associated with $\mathrm{H}$ pylori infection. Greater awareness of the spectrum of diseases associated with $H$ pylori may well lead to their increased recognition in the pediatric population. Some diseases, particularly Crohn's disease, but also human immunodeficiency virus infection, have a negative association with $H$ pylori that appears not to be simply a result of the excess antibiotic therapy that these patients receive. These variations in association and reactions to $H$ pylori, some of which are age-related, may allow the different host responses to $H$ pylori that occur in humans to be examined.

Key Words: Helicobacter pylori; Pediatrics

\section{Pathobiologie de l'infection à Helicobacter pylori chez l'enfant}

RÉSUMÉ : Dans la population pédiatrique, les associations de Helicobacter pylori avec la gastrite, l'ulcère gastrique, la duodénite et l'ulcère duodénal, et avec les métaplasies de la surface du duodénum et des troubles de l'axe cellules D-cellules G entraînant une hypergastrinémie, sont bien établies et, sur beaucoup de points, ressemblent aux associations que l'on observe chez l'adulte. L'éradication de $H$. pylori conduit invariablement au renversement de ces affections dans le temps. On pense également que la métaplasie de la surface gastrique est plus importante chez l'enfant infecté par H.pylori, et qu'elle pourrait être la localisation d'une infection duodénale à $H$. pylori et aux érosions duodénales associées ou aux ulcères. Il n'y a aucun consensus sur le fait que l'infection à $H$. pylori chez l'enfant soit plus ou moins grave que chez l'adulte. Dans une cohorte pédiatrique, $H$. pylori était associé à une augmentation de l'intensité de l'inflammation, tandis que d'autres études permettent de croire qu'une inflammation aiguë serait globalement moins intense chez l'enfant mais que qu'une inflammation chronique pourrait être plus intense, y compris une hyperplasie lymphoïde qui, à son tour, pourrait être en corrélation avec les lésions nodulaires observées à l'endoscopie. L'hyperplasie lymphoïde et la gastrite nodulaire semblent plus fréquentes chez l'enfant que chez l'adulte, mais régressent habituellement à la suite de l'éradication de $H$. pylori. Cependant, chez l'enfant, d'autres affections ou d'autres anomalies morphologiques, y compris une certaine réduction des glandes (atrophie), quelquefois une métaplasie intestinale, des maladies lymphoprolifératives y compris un lymphome des muqueuses de grade peu élevé associé à des tissus lymphoïdes, une gastrite lymphocytaire et une gastrite hypertrophique ou maladie de Ménétrier, sont beaucoup moins fréquemment associées à $H$. pylori que chez l'adulte. D'autres associations sont rarement observées chez l'enfant, principalement parce que le temps requis pour qu'elles se développent amène l'individu à l'âge adulte ; par exemple, alors qu'une métaplasie intestinale survient dans la population pédiatrique, les complications d'un adénome avec dysplasie ou d'un carcinome sont rares. Chez l'adulte, des polypes inflammatoires et hyperplasiques, une gastrite atrophique et une anémie pernicieuse et, chez certains patients, des granulomes (gastrite granulomateuse), peuvent aussi être associés à une infection à $H$. pylori. Une plus grande connaissance du spectre des affections associées à $H$. pylori

voir page suivante 
pourrait améliorer leur diagnostic dans la population pédiatrique. Certaines affections, en particulier la maladie de Crohn, mais également l'infection au virus de l'immunodéficience humaine, ont une association négative avec $H$. pylori et qui ne semble pas seulement être le résultat d'une antibiothérapie excessive que ces patients reçoivent. Ces variations ainsi que les réactions associées à $H$. pylori, dont certaines sont liées à l'âge, pourraient permettre aux différentes réponses de l'hôte envers $H$. pylori qui surviennent chez l'homme, d'être étudiées.
$\mathrm{I}_{\mathrm{p}}^{\mathrm{n}}$ $\mathrm{n}$ the pediatric population, the associations of Helicobacter pylori with disease are often similar to those seen in adults, but there are major differences. The purpose of this paper is to discuss the pathobiology of diseases associated with $H$ pylori, which of them occur in the pediatric population and whether they are similar or identical to their adult counterparts; draw attention to diseases that are not well recognized but that occur in the pediatric age range and may be associated with a particular genetic background or strain of $\mathrm{H} p \mathrm{y}$ lori; and note the diseases that have a negative association with $H$ pylori because these also affect the pathobiology of the disease. The differences in $H$ pylori-associated diseases between the pediatric and adult populations are also explored.

\section{DISEASES OF THE GASTROINTESTINAL TRACT ASSOCIATED WITH H PYLORI}

Gastroduodenal diseases associated with $H$ pylori infection in the pediatric population, and those limited to the adult population, are listed in Tables 1 and 2, respectively. Table 3 lists the conditions that have a negative association with H pylori infection.

Initial infection and spontaneous regression: In both adults and children, acute $H$ pylori infection results in an acute purulent gastritis characterized by a lamina propria rich in neutrophils, in many ways similar to what occurs with acute infectious colitis. In adults, spontaneous regression of $\mathrm{H}$ pylori without treatment is rare. While in most studies the acquisition rate increases with age, one study from Peru suggested that the prevalence drops from $71.4 \%$ to $47.9 \%$ between six and 30 months of age, raising the question of whether spontaneous eradication occurs in some infants (1). This study was carried out using urea breath testing, which is associated with problems in the very young and uses very high amounts of urea. In most children, there is a transition to chronic, active gastritis as chronic inflammatory cells

\section{TABLE 1 \\ Gastroduodenal diseases associated with Helicobacter pylori infection in the pediatric population}

Gastritis: acute, chronic, erosions, ulcers

Nodular gastritis: endoscopic

Increased intensity of gastritis

Lymphoid hyperplasia: antrum and corpus

Duodenal disease: gastric surface metaplasia with or without $H$ pylori colonization, acute and chronic inflammation, erosions and ulcers

Disorders of the D cell-G cell axis

Gastric intestinal metaplasia (rare) (lymphocytes and plasma cells) become part of the lamina propria infiltrate. A second study showed a similar trend (2). Intensity of acute and chronic gastritis, lymphoid hyperplasia and endoscopic nodularity: Acute and chronic gastritis occurs in children with $\mathrm{H}$ pylori infection as in adults, and is usually antral predominant pangastritis. The densities of all inflammatory cells in $H$ pylori-positive children have been measured and markedly exceed those in $\mathrm{H}$ pylori-negative children. Furthermore, the excess of inflammatory cells decreases following $H$ pylori eradication $(3,4)$.

A major question is whether the inflammatory response in the pediatric population is the same as that in the adult.

Intensity of inflammation: In both adults and children, there may well be an overall relationship between the number of organisms and the intensity of the inflammatory infiltrate, but there is much individual variation. Intense inflammation tends to occur in patients with cagA-positive $H$ pylori strains $(5,6)$. Furthermore, the intensity of the inflammatory infiltrate varies considerably on a geographic basis, which may also be reflected in the intensity of pediatric inflammation. In Canada, $\mathrm{H}$ pylori infection in adults is typically a low grade, chronic, active disease in that neutrophils are usually present. In much of Asia and South America, $H$ pylori infection tends to be accompanied by a greater neutrophilic component, while in Africa, it is often similar to that in North America and may even lack acute inflammation (personal observations). This may well reflect the absence of active cagA genes or other active genes in the pathogenicity island.

One study from Germany looked at 50 biopsies, each from three groups of individuals with $H$ pylori infection - one group of children with a mean age of 11 years, and two adult groups with mean ages of 43 and 70 years, respectively. Two biopsies were taken from the antrum and corpus, and examined 'blind'. Parameters that were increased in children were

\section{TABLE 2}

Diseases that are associated with Helicobacter pylori in adults but rarely in children

Gastric atrophy/pernicious anemia

Dysplasia/adenoma

Carcinoma: intestinal and diffuse

Inflammatory polyps

Low grade mucosal-associated lymphoid tissue lymphoma

Lymphocytic gastritis

Hypertrophic gastritis/Menetrier's disease 
the degree and activity of gastritis, the extent of $\mathrm{H}$ pylori colonization and the degree of regenerating (mucin depleted) epithelium; there was also an increased number of lymphoid follicles in both the antral and corpus mucosa. Conversely, but not surprisingly, there was an increase in the degree of atrophic gastritis and intestinal metaplasia in adults (7). These features suggest a greater intensity of both the acute and chronic inflammatory reaction in children than in adults. This chronic inflammation is reflected in both the lymphoplasmacytic reaction of the lamina propria and the formation of lymphoid follicles. A Brazilian study found, rather surprisingly, that children with duodenal ulcers had more inflammation in the oxyntic (acid-bearing) mucosa than did adults with duodenal ulcers (8). However, other data from North America and Europe suggest that children in these series have less acute inflammation and a more prominent chronic inflammatory infiltrate $(3,4,9)$ (Jones et al, personal communication; Whitney et al personal communication).

Lymphoid follicles and nodular gastritis: Lymphoid follicles and nodular gastritis are common in the pediatric age group but are also found, albeit less frequently, in adults. An Australian study suggested that children had more antral nodular gastritis endoscopically but less acute inflammation in their $\mathrm{H}$ pylori-associated gastritis than did adults from the same population; fewer children had peptic ulcer disease than adults, and only one-third of both duodenal and gastric ulcers were associated with $H$ pylori (9). These results contrast with those of a Brazilian study in which all children with duodenal ulcers were $H$ pylori-positive (8). Inevitably, the question of whether other biases occur, such as referral biases, is raised; children with upper gastrointestinal symptoms may be referred much more readily than their adult counterparts. In a Finnish study in which absolute numbers of inflammatory cells were counted, children with $H$ pylori-positive gastritis had many more neutrophils than their $\mathrm{H}$ pylori-negative gastritis controls, and about $50 \%$ more chronic inflammatory cells in the lamina propria (3). H pylori-infected children had about one neutrophil for every 10 lymphocytes and plasma cells combined; this count seems quite similar to that seen in adults in Canada.

Endoscopic appearances: These changes in inflammation manifest endoscopically as endoscopic nodularity. There are two potential causes. First, lymphoid nodules, invariably with germinal centres, can form nodules in all parts of the gastrointestinal tract, including the antrum and the corpus. Second, the inflammatory reaction alone can result in endoscopic nodularity ('nodular gastritis'), which may well represent exaggerations of the normal areae gastricae. All of these changes resolve following eradication of $\mathrm{H}$ pylori - further indirect evidence that these changes are related to $\mathrm{H}$ pylori. In one study, all 25 patients (age range 20 to 42 years) with antral nodularity had biopsy specimens positive for $H$ pylori. Twenty (80\%) had lymphoid follicles; antral nodularity subsided, and there was marked regression of the lymphoid follicles in patients in whom $H$ pylori was successfully eradicated (10). In another study, endoscopic gastritis, often nodular,
TABLE 3

Conditions that have a negative association with Helicobacter pylori infection

Crohn's disease

Human immunodeficiency virus infection

Fundic gland polyps

was noted in $60 \%$ of patients with gastritis who were $\mathrm{H}$ pylori-positive, but also in $46 \%$ of those who were $H$ pylori-negative, suggesting that this was not a specific change but a reflection of inflammation (11). While lymphoid follicles are common almost to the point of being the rule in children (12), they are also quite common in adults (10) This is understandable because histological nodules of lymphoid tissue produce endoscopic lesions at a variety of sites in the gastrointestinal tract. Whatever the cause, the nodules resolve following eradication of $H$ pylori $(4,10,12)$. Lymphoid nodules without germinal centres are normally seen throughout the gastrointestinal tract, including the stomach.

Is inflammation always present in $\mathrm{H}$ pylori-associated gastritis in children?: Although H pylori has been seen in apparantly histologically normal mucosa, substantiation of such observations in the literature is dubious. One retrospective study of 80 infected children and adolescents aged two months to 22 years found normal mucosa histologically in 22 of 80 patients $(27.5 \%)$ (13). The question then becomes that of what is normal? In the small and large bowel, a moderate lymphoplasmacytic infiltrate is normal; however, the stomach is virtually a virgin organ immunologically, so that anything other than an occasional inflammatory cell is abnormal. It is also possible that there may be geographic variations in what is accepted as normal, as in the small bowel, but this area is virtually unexplored. I am unaware of a single case of $H$ pylori infection in which the number of inflammatory cells in the lamina propria was not increased, even though, in theory, this might occur in immune deficiency syndromes. Biopsies seen personally from those patients were purulent chronically. Helicobacter heilmannii also occurs in children and may be accompanied by less intense inflammation than is H pylori (14).

Perturbations in the D cell-G cell axis: As in adults, $H$ pylori infection in children results in decreased numbers of $\mathrm{D}$ cells and, therefore, of somatostatin, resulting in hypergastrinemia, which appears to be more frequent in younger than in older children (15), and in children than in adults (16). Following eradication of $\mathrm{H}$ pylori, the hypergastrinemia is abolished, and the number of antral endocrine cells and the D cell to $G$ cell ratio return to normal $(17,18)$.

Atrophic gastritis and intestinal metaplasia: Considerable caution is necessary when interpreting data using the terms 'atrophic gastritis' and 'intestinal metaplasia'. Some authors consider intestinal metaplasia to be an integral part of atrophic gastritis; the rationale is that because metaplasia is present, a loss of glands occurs, and the mucosa is, by definition, atrophic. However, others have noted that intestinal metaplasia can be present without a loss of glands in the adjacent 
mucosa, presumably as a response to local injury. The trend is, therefore, to separate these two conditions, so that it is possible to consider atrophic gastritis with or without intestinal metaplasia, and intestinal metaplasia with or without associated atrophic gastritis (19).

In adults, there is a strong case to suggest that atrophy and carcinoma go hand in hand, especially in high risk regions (20). These changes, which are of much greater significance in oxyntic rather than antral mucosa, are more common in adults than in children (7), increase with age (21), are likely accelerated by cagA + strains of $H$ pylori through a glycentindependent mechanism (22) and are likely not reversible following eradication (23), although progression is likely halted. Interestingly, deep inflammation of the oxyntic mucosa in some patients results in a marked hypochlorhydria that is reversible following eradication of $\mathrm{H}$ pylori (24).

Peptic ulcer disease: The role of $\mathrm{H}$ pylori in pediatric ulcer disease varies tremendously; in some series, virtually all patients with peptic ulcer disease are infected with $H$ pylori (8), while in other series, H pylori infection seems to be less common $(4,9,25,26)$, presumably because it is either missed (eg, due to a small numbers of organisms, a proximal shift in their distribution, or therapy with proton pump inhibitors or antibiotics) or because the ulcer is due to other factors such as nonsteroidal anti-inflammatory drug use. Biopsies must be obtained from oxyntic as well as antral mucosa when searching for $\mathrm{H}$ pylori on biopsy because this may be the only site in which they are found. In children, duodenal ulcer is much more common than gastric ulcer, although prepyloric ulcers and duodenal ulcers are both strongly associated with severe antral gastritis and cagA+ strains of $H$ pylori $(5,27)$. Proximal gastric ulcers are uncommon in children and more strongly associated with a moderate $H$ pylori pangastritis. Duodenal ulcers also seem to be associated with gastric surface metaplasia in the duodenum and with $\mathrm{H}$ pylori colonization of such mucosa; the combination of both is particularly likely to be associated with ulceration (28-32). Healing of duodenal ulcers is frequently accompanied by re-epithelialization of the duodenal ulcer base by gastric rather than intestinal mucosa (33). However, it is clear that in both adults and children, the presence of severe antral inflammation correlates with an increased likelihood of duodenal ulceration $(5,27,29)$.

\section{OTHER DISEASES LESS CONSISTENTLY ASSOCIATED WITH H PYLORI INFECTION IN CHILDREN}

Lymphocytic gastritis: Lymphocytic gastritis is simply an excess of intraepithelial lymphocytes (IELs). Gastric mucosa usually has no more than one IEL per five epithelial cells, although in lymphocytic gastritis, the number of IELs frequently exceeds 25. However, a mild but distinct intraepithelial lymphocytosis occurs in patients with celiac disease $(34,35)$, but increased numbers are also seen focally in H pylori gastritis, Crohn's disease (36) and some forms of Menetrier's disease that may respond to eradication (37-39). About $12 \%$ of both adults (40) and children (4) with $\mathrm{H}$ py- lori have lymphocytic gastritis, although evidence of infection may be serological rather than morphological because organisms may be difficult or impossible to identify in sections.

The natural history of $H$ pylori-associated lymphocytic gastritis has been examined in adults. In one series, nine of $96(9 \%)$ patients had features of lymphocytic gastritis at the first examination, and $12.5 \%$ had features of lymphocytic gastritis at the second examination. Persistent lymphocytic gastritis was found in 78\% (seven of nine) at follow-up a decade later; in two patients, the diagnostic features of lymphocytic gastritis had disappeared, and in five, a new diagnosis of lymphocytic gastritis was made at the second examination. At the second examination, nine of 12 patients were $H$ pylori-positive histologically, while all had specific antibodies to $H$ pylori. The lymphocytic gastritis patients had higher grades of gastritis, and more neutrophils, eosinophils and mononuclear inflammatory cells; however, these patients had fewer organisms than the $\mathrm{H}$ pylori-positive patients without lymphocytic gastritis. The appearance of lymphocytic gastritis during the 10 -year interval was associated with increases in the grades of corpus gastritis and neutrophils. During the follow-up, patients with lymphocytic gastritis, but not $H$ pylori-positive patients without lymphocytic gastritis, appeared to have a significant increase in the grade of intestinal metaplasia (40).

Granulomatous gastritis: In one study of granulomatous gastritis, $\mathrm{H}$ pylori may have been associated with granulomata in approximately $10 \%$ of patients. There was insufficient power in the study to distinguish whether this frequency exceeded that of chance, but the possibility of an association remains (41).

Inflammatory polyps: Case reports and small series indicate that gastric inflammatory polyps, which may consist primarily of granulation tissue, are superficially ulcerated and bleed. When associated with $H$ pylori infection, the polyps may regress with eradication of the organism $(42,43)$.

Gastric mucosal-associated lymphoid tissue lymphoma: There are occasional examples of what appears to be low grade mucosal-associated lymphoid tissue (MALT) lymphoma. The MALT in a 14-year-old girl regressed following eradication of $H$ pylori (44). An apparent MALT lymphoma in the minor salivary gland of another child also regressed following eradication of gastric $\mathrm{H}$ pylori (45). Gastric MALT lymphomas may be associated with lymphocytic gastritis (46). Adenomatous polyps and carcinoma: Gastric adenomas and carcinomas are so rare in children that there is insufficient evidence to confirm that they have an association with $H$ pylori. Even in adults, in whom there is a well established association between $H$ pylori and carcinoma, the influence of $H$ pylori eradication on gastric neoplasia is uncertain. In a Japanese study in which patients had endoscopic resection of gastric carcinomas, half had their $\mathrm{H}$ pylori eradicated and half did not. Ten per cent of patients in whom eradication was not carried out developed an apparent second gastric carcinoma compared with none of those in the eradication group (47). However, many early gastric 'carcinomas' are 
noninvasive using Western criteria (48). Therefore, while something seems to have been prevented in these patients, it is unclear exactly what has happened. The possibility that some of these cancers might have represented severe reactive changes cannot be excluded.

\section{REFERENCES}

1. Klein PD, Gilman RH, Leon-Barua R, Diaz F, Smith EO, Graham DY. The epidemiology of Helicobacter pylori in Peruvian children between 6 and 30 months of age. Am J Gastroenterol 1994;89:2196-200.

2. Kehrt R, Becker M, Brosicke H, Kruger N, Helge H. Prevalence of Helicobacter pylori infection in Nicaraguan children with persistent diarrhea, diagnosed by the $13 \mathrm{C}$-urea breath test. J Pediatr Gastroenterol Nutr 1997;25:84-8.

3. Ashorn M, Ruuska T, Karikoski R, Valipakka J, Maki M. Gastric mucosal cell densities in Helicobacter pylori-positive and -negative dyspeptic children and healthy controls. J Pediatr Gastroenterol Nutr 1994;18:146-51.

4. Mahony MJ, Wyatt JI, Littlewood JM. Management and response to treatment of Helicobacter pylori gastritis. Arch Dis Child 1992;67:940-3.

5. Warburton VJ, Everett S, Mapstone NP, Axon AT, Hawkey P, Dixon MF. Clinical and histological associations of cagA and vacA genotypes in Helicobacter pylori gastritis. J Clin Pathol 1998;51:55-61.

6. Pilotto A, Rassu M, Bozzola L, et al. Cytotoxin-associated gene A-positive Helicobacter pylori infection in the elderly. Association with gastric atrophy and intestinal metaplasia. J Clin Gastroenterol 1998;26:18-22

7. Meining A, Behrens R, Lehn N, Bayerdorffer E, Stolte M. Different expression of Helicobacter pylori gastritis in children: evidence for a specific pediatric disease? Helicobacter 1996;1:92-7.

8. Queiroz DM, Rocha GA, Mendes EN, et al. Differences in distribution and severity of Helicobacter pylori gastritis in children and adults with duodenal ulcer disease. J Pediatr Gastroenterol Nutr 1991; 12:178-81.

9. Mitchell HM, Bohane TD, Tobias V, et al. Helicobacter pylori infection in children: potential clues to pathogenesis. J Pediatr Gastroenterol Nutr 1993;16:120-5.

10. Sbeih F, Abdullah A, Sullivan S, Merenkov Z. Antral nodularity, gastric lymphoid hyperplasia, and Helicobacter pylori in adults.

J Clin Gastroenterol 1996;22:227-30.

11. Lamireau T, Rigot A, Megraud F, de Mascarel A. [Helicobacter pylori gastritis in children]. Arch Pediatr 1995;2:310-6.

12. Kato S, Takeyama J, Ebina K, Naganuma H. Omeprazole-based dual and triple regimens for Helicobacter pylori eradication in children. Pediatrics 1997;100:E3.

13. Gottrand F, Cullu F, Turck D, et al. Normal gastric histology in Helicobacter pylori-infected children. J Pediatr Gastroenterol Nutr 1997;25:74-8.

14. Oliva MM, Lazenby AJ, Perman JA. Gastritis associated with Gastrospirillum hominis in children. Comparison with Helicobacter pylori and review of the literature. Mod Pathol 1993;6:513-5.

15. McCallion WA, Ardill JE, Bamford KB, Potts SR, Boston VE. Age dependent hypergastrinaemia in children with Helicobacter pylori gastritis - evidence of early acquisition of infection. Gut 1995;37:35-8.

16. McCallion WA, Bailie AG, Ardill JE, Bamford KB, Potts SR, Boston VE. Helicobacter pylori, hypergastrinaemia, and recurrent abdominal pain in children. J Pediatr Surg 1995;30:427-9.

17. Kozlowski W, Kulig A, Czkwianianc E, Bak-Romaniszyn L, Planeta-Malecka I, Przybylska B. Morphological and immunohistochemical examinations of the dynamic changes of gastric mucosa associated with the treatment of Helicobacter pylori infection in children. Rocz Akad Med Bialymst 1995;40:678-84.

18. Queiroz DM, Moura SB, Mendes EN, Rocha GA, Barbosa AJ, de Carvalho AS. Effect of Helicobacter pylori eradication on G-cell and D-cell density in children. Lancet 1994;343:1191-3.

19. Dixon MF, Genta RM, Yardley JH, Correa P. Classification and grading of gastritis. The updated Sydney System. International Workshop on the Histopathology of Gastritis, Houston 1994. Am J Surg Pathol 1996;20:1161-81.

20. Sipponen P, Kimura K. Intestinal metaplasia, atrophic gastritis and stomach cancer: trends over time. Eur J Gastroenterol Hepatol 1994;6(Suppl 1):S79-83.

21. Rugge M, Di Mario F, Cassaro M, et al. Pathology of the gastric antrum and body associated with Helicobacter pylori infection in non-ulcerous patients: is the bacterium a promoter of intestinal metaplasia? Histopathology 1993;22:9-15.
22. Sozzi M, Valentini M, Figura N, et al. Atrophic gastritis and intestinal metaplasia in Helicobacter pylori infection: the role of CagA status. Am J Gastroenterol 1998;93:375-9.

23. van der Hulst RW, van der Ende A, Dekker FW, et al. Effect of Helicobacter pylori eradication on gastritis in relation to cagA: a prospective 1-year follow-up study. Gastroenterology 1997;113:25-30.

24. El-Omar EM, Oien K, El-Nujumi A, et al. Helicobacter pylori infection and chronic gastric acid hyposecretion. Gastroenterology 1997;113:15-24.

25. Chong SK, Lou Q, Asnicar MA, et al. Helicobacter pylori infection in recurrent abdominal pain in childhood: comparison of diagnostic tests and therapy. Pediatrics 1995;96:211-5.

26. Hassall E, Dimmick JE. Unique features of Helicobacter pylori disease in children. Dig Dis Sci 1991;36:417-23.

27. Bak-Romaniszyn L, Malecka-Panas E, Zeman K, et al. Helicobacter pylori infection in the etiopathogenesis of duodenal ulcer in children. J Physiol Pharmacol 1996;47:209-20.

28. Elitsur Y, Triest WE. Is duodenal gastric metaplasia a consequence of Helicobacter pylori infection in children? Am J Gastroenterol 1997;92:2216-9.

29. Bonamico M, Mariani P, Magliocca FM, et al. Helicobacter pylori duodenal colonization in children. Acta Paediatr 1997;86:356-60.

30. Khulusi S, Mendall MA, Badve S, Patel P, Finlayson C, Northfield TC. Effect of Helicobacter pylori eradication on gastric metaplasia of the duodenum. Gut 1995;36:193-7.

31. Harris AW, Gummett PA, Walker MM, Misiewicz JJ, Baron JH. Relation between gastric acid output, Helicobacter pylori, and gastric metaplasia in the duodenal bulb. Gut 1996;39:513-20.

32. Gormally SM, Kierce BM, Daly LE, et al. Gastric metaplasia and duodenal ulcer disease in children infected by Helicobacter pylori. Gut 1996;38:513-7.

33. Urakami Y, Kimura M, Seki H. Gastric metaplasia and Helicobacter pylori. Am J Gastroenterol 1997;92:795-9.

34. Vogelsang H, Oberhuber G, Wyatt J. Lymphocytic gastritis and gastric permeability in patients with celiac disease. Gastroenterology 1996;111:73-7.

35. Feeley KM, Heneghan MA, Stevens FM, McCarthy CF. Lymphocytic gastritis and coeliac disease: evidence of a positive association. J Clin Pathol 1998;51:207-10.

36. Wright CL, Riddell RH. Histology of the stomach and duodenum in Crohn's disease. Am J Surg Pathol 1998;22:383-90.

37. Kawasaki M, Hizawa K, Aoyagi K, Nakamura S, Fujishima M. Menetrier's disease associated with Helicobacter pylori infection: resolution of enlarged gastric folds and hypoproteinemia after antibacterial treatment. Am J Gastroenterol 1997;92:1909-12.

38. Yamada M, Sumazaki R, Adachi H, et al. Resolution of protein-losing hypertrophic gastropathy by eradication of Helicobacter pylori. Eur J Pediatr 1997;156:182-5.

39. Bayerdorffer E, Ritter MM, Hatz R, Brooks W, Stolte M. Menetrier's disease and Helicobacter pylori. N Engl J Med 1993;329:60.

40. Niemela S, Karttunen T, Kerola T, Karttunen R. Ten year follow up study of lymphocytic gastritis: further evidence on Helicobacter pylori as a cause of lymphocytic gastritis and corpus gastritis. J Clin Pathol 1995;48:1111-6.

41. Shapiro JL, Goldblum JR, Petras RE. A clinicopathologic study of 42 patients with granulomatous gastritis. Is there really an "idiopathic" granulomatous gastritis? Am J Surg Pathol 1996;20:462-70.

42. Suzuki S, Ohkusa T, Shimoi K, Horiuchi T, Fujiki K, Takashimizu I. Disappearance of multiple hyperplastic polyps after the eradication of Helicobacter pylori. Gastrointest Endosc 1997;46:566-8.

43. Ohkusa T, Takashimizu I, Fujiki K, et al. Disappearance of hyperplastic polyps in the stomach after eradication of Helicobacter pylori. A randomized, clinical trial. Ann Intern Med 1998;129:712-5.

44. Blecker U, McKeithan TW, Hart J, Kirschner BS. Resolution of Helicobacter pylori-associated gastric lymphoproliferative disease in a child. Gastroenterology 1995;109:973-7.

45. Berrebi D, Lescoeur B, Faye A, Faure C, Vilmer E, Peuchmaur M. MALT lymphoma of labial minor salivary gland in an immunocompetent child with a gastric Helicobacter pylori infection. J Pediatr 1998;133:290-2.

46. Miettinen A, Karttunen TJ, Alavaikko M. Lymphocytic gastritis and Helicobacter pylori infection in gastric lymphoma. Gut 1995;37:471-6.

47. Uemura M, Mukai T, Okamoto S, et al. Helicobacter pylori eradication inhibits growth of intestinal type of gastric cancer in initial stage. Gastroenterology 1996;110:A282.

48. Schlemper RJ, Itabashi M, Kato Y, et al. Differences in diagnostic criteria for gastric carcinoma between Japanese and western pathologists. Lancet 1997;349:1725-9. 


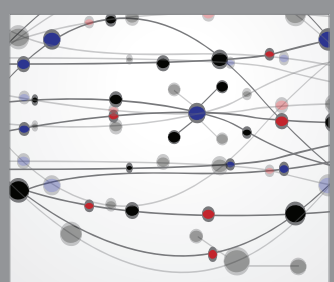

The Scientific World Journal
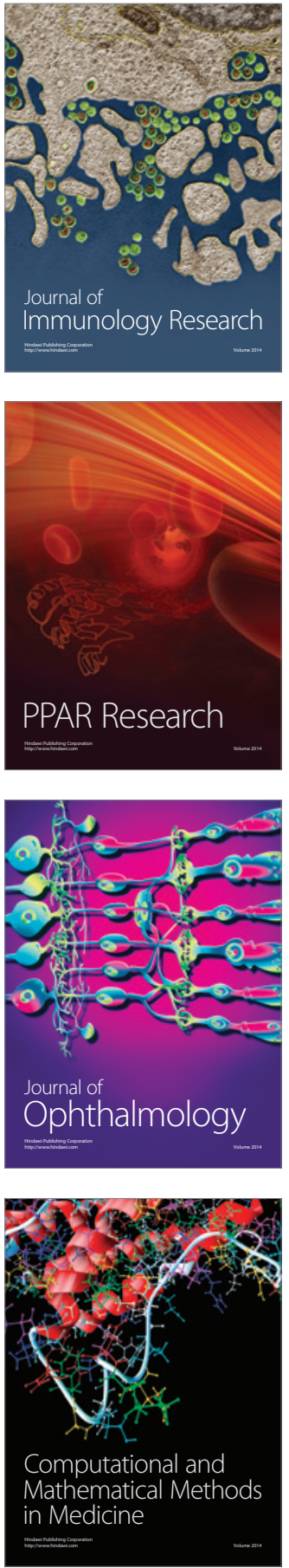

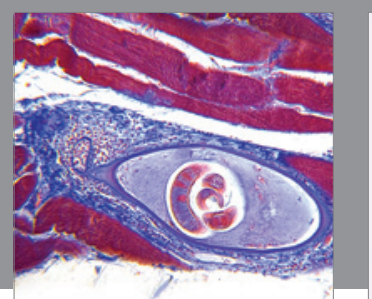

Gastroenterology Research and Practice

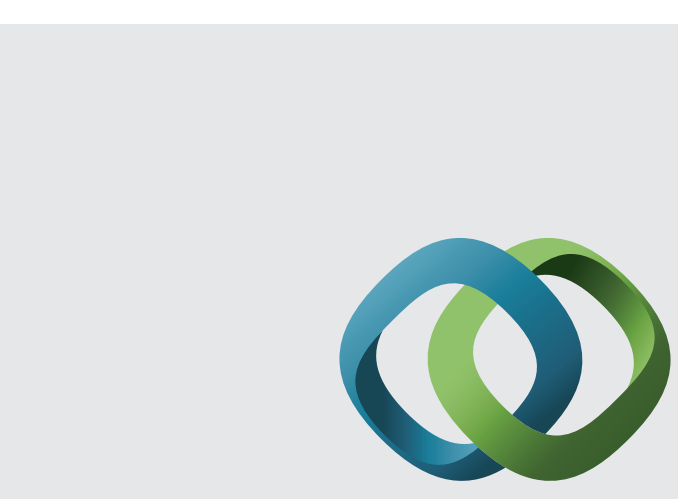

\section{Hindawi}

Submit your manuscripts at

http://www.hindawi.com
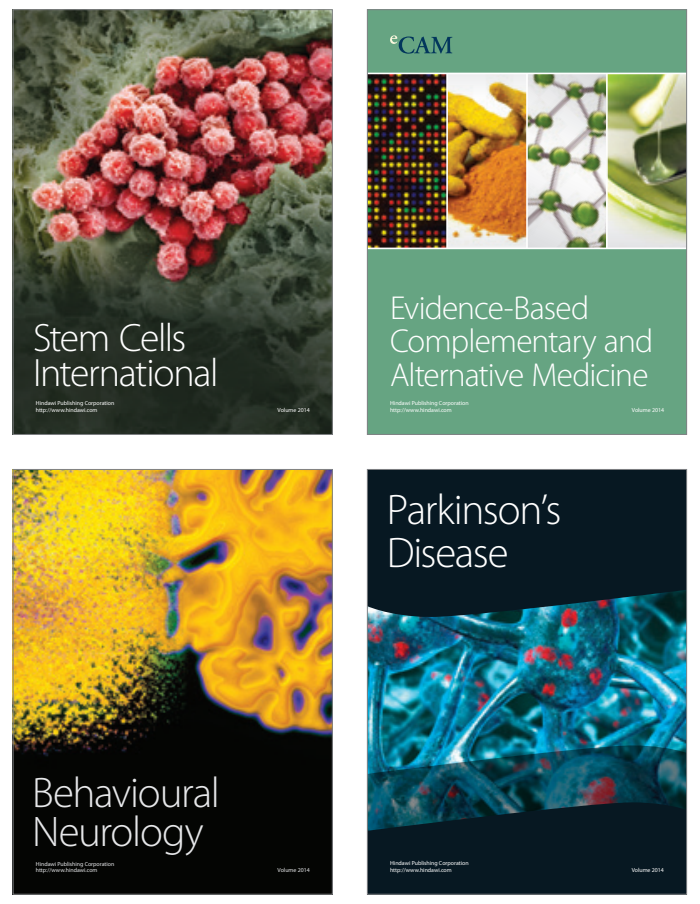
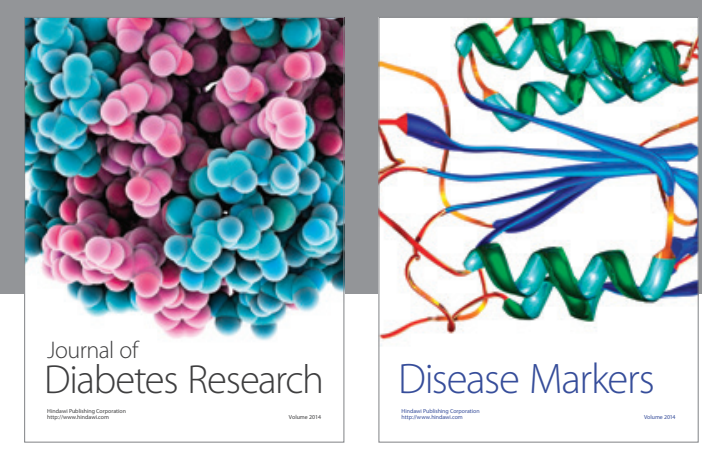

Disease Markers
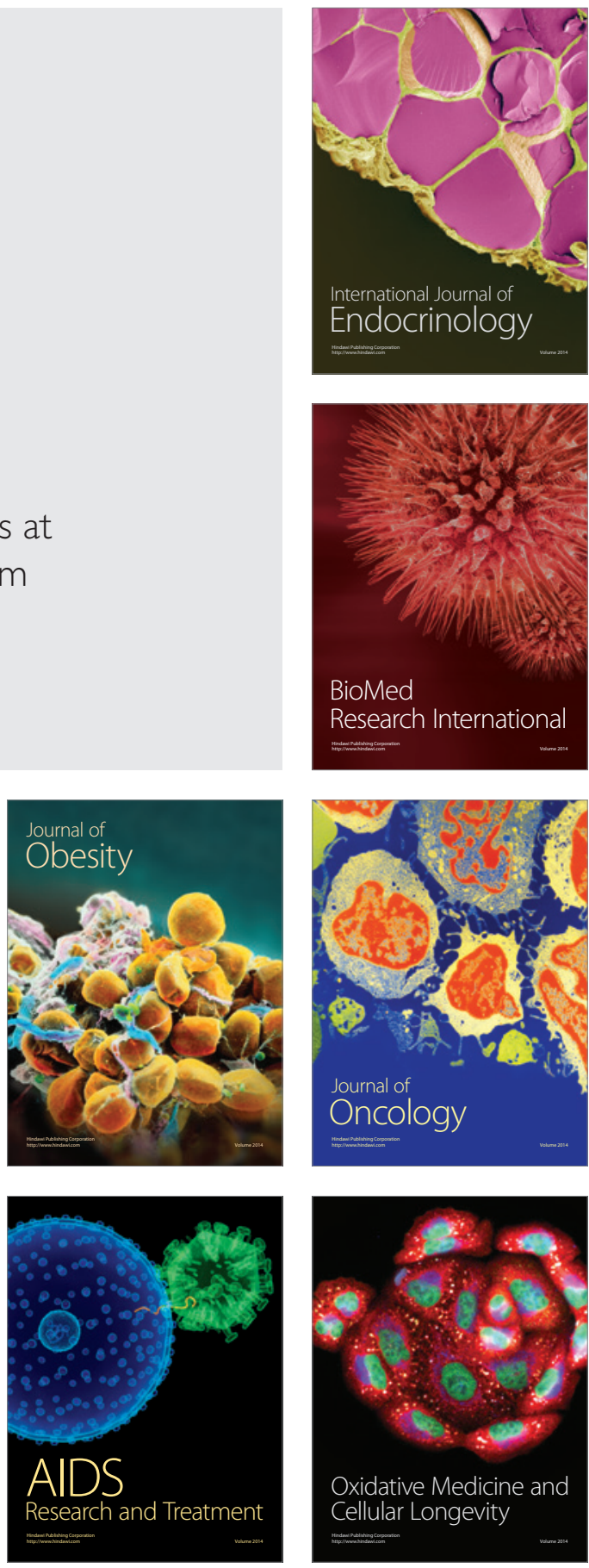